\title{
ВАН И НАПОЉЕ, ЊИМА СРОДНЕ И С ЊИМА ПОВЕЗАНЕ РЕЧИ У СРПСКОМЕ ЈЕЗИКУ: ПРИЛОГ ПРОУЧАВАЮУ ${ }^{* *}$
}

\begin{abstract}
У раду се према ограниченој историјској и дијалекатској грађи сагледава развој прилошких лексема са значењем 'напоље', 'напољу', 'споља' у српској језичкој средини до савременог књижевнојезичког стања које је у XX веку неоправдано искоришћено за поларизацију двеју варијаната „српскохрватскога књижевног језика”.

Кључне речи: ван, вани, изван, напоље, напољу, споља, надвор, надвору, здвора, историја језика с дијалектологијом, савремени језик.
\end{abstract}

Словенски језици наслеђују прилог * vъnъ чија је етимологија недовољно јасна, али изгледа да је најуверљивије тумачење да се овде ради о окамењеном облику именице чија је паралела литванско илативно laukañ, с истим значењем као словенско вАн (такође лит. laukè 'споља' - лит. laũkas 'поље', Дерксен 2008: s. v. *vъnъ, Фасмер I: s. v. вон ${ }^{1}$, уп. вне). Овакву етимологију поткрепљује потпуна семантичка паралела и потоњи развој у правцу срастања и лексикализације предлошко-падежних конструкција, у прозодијском смислу и акценатских целина, нӓ йоље, нӓ_йољу у српском језику. Уједно, то је сведочанство дубље словенске старине овога српског устаљеног споја. Први словенски књижевни језик имао је посведочене три прилошке форме именичког порекла: вънъ 'напоље', вънь 'напољу', нұвъног 'споља' (CC: s. vv.). - Све су то петрифицирани падежни облици, акузатив, локатив, генитив (Скок III: s. v. vän², Ђорђић 1975: 207).

На прасловенском језичком ступњу антоним поменутом прилогу гласио je * trb и он је управо такав посведочен у старословенском Супрасаљском

"viktor.savic@isj.sanu.ac.rs

** Рад је настао у оквиру пројекта „Обрада старог српског писаног наслеђа и Речник црквенословенског језика српске редакције” (Министарство просвете, науке и технолошког развоја Републике Србије, бр. 178030). 
зборнику (уп. Ђорђић 1975: 207), као и у староруским споменицима (само деназализовано, Дерксен 2008: s. v. * $q$ trb). Међутим, већ у старословенским класичним споменицима преовладаће његова сложена варијанта вънхтрь (СС: s. vv.). По среди је плеонастични спој с предлогом/префиксом * vъn-у којем се и чува финално - $n$ од испадања. Тако је добијена параетимолошка веза међу антонимима: вънъ / вън-хтрь. После преласка иницијалног $w$ - $>u$ - у српском језику по свршетку његове конститутивне фазе (XI век), ови облици више нису један другом представљали узајамни структурни ослонац, па су се тиме створили услови да сваки од њих крене својим путем. Отворена је могућност да у средишњим српским говорима у наредним столећима дође до постепене супституције првог члана антонимског пара неким другим, тј. од тада можемо очекивати лексикализацију поменутих конструкција у прилоге нАпољЕ, НАПољу и друге. О том потискивању могло би сведочити и ширење споја с предлогом/префиксом из- (*jbz-), у почетку ограничено на генитив (уп. стсл. ндвъноү, CC: s. v.). Тамо где је уопштен облик извАн, заједно с одговарајућим изведеницама (нпр. извАњи, извАњАц, в. ниже), протетички се спречава промена $v ъ n>* u n$, одражена, на пример, код vъz > uz (уп. Скок III: s. v. vän²). Можда о овој тенденцији сведочи нешто већи број примера код Даничића у Рјечнику из књижевних старина српских (I: s. vv. нұвьнь, вьнь).

Српски дијалекти показују другачију ситуацију од историјске, али са занимљивом лексичком дисперзијом којом се илуструју различите језичке развојне фазе и разноврсни утицаји и додири на терену. Нажалост, домаћи дијалекатски речници превасходно су диференцијалног карактера (мада постоје и изузеци), што отежава рад на нашој теми. ${ }^{1}$ Наиме, у њима примењеном приступу обично нема места за општу лексику под коју се подводе и наши примери, јер се општи лексички фонд „подразумева”! Зато, без опсежног теренског истраживања које превазилази реалне оквире нашега опита, није могућан исцрпан табеларан преглед и уцртавање изолекси на западнојужнословенску карту, као пожељан исход. У анализи смо се послужили дијалекатским текстовима и студијама објављеним у Српском дијалектолошком зборнику (I-LXIV, 1905-2017), где је најцеловитији приказ српских народних говора. Упркос изреченим ограничењима, из доступног материјала сагледавамо следеће: на периферији - шире схваћеној, пре свега западној и јужној, донекле се задржавају општесловенске (или њима мотивисане) прилошке форме ВАн, вАни или сл., али је расположиви материјал у овом случају нарочито произвољан; потврде налазимо у Призрену: ви́н, ви́нке (Реметић 1996: 385), северној Метохији: вӓн [с предлогом извӓн] (Букумирић 2012: s. v.), [у књажевачко-сврљишком говору: предлог ван (Богдановић 1979: 100), Ужичкој Црној гори: предлог ван (Марковић С. 2011: 603), Војводини: предлог вӓн (РСГВ)], на периферији Црне Горе у општини Плав: вӓни (Јокић 2012: s. v.), у јужној Босни и високој Херцеговини прилог: ва̀ни (Ђуровић 1992: 321), на Конавлима (Кашић 1995: 374) и у Дубровнику: ваิнка (Младошић/Миливојевић 2011:

${ }^{1}$ За консултоване речнике в. Извори и литература, а за ширу информацију преглед: Недељков/Марковић 2015. 
s. v.), али с деиктичким проширењем, заступљеним по јадранским отоцима и на ширем словенском плану, на пример у Украјини и Русији (в. Скок III: s. v. vän²), у ливањско-дувањским говорима: ваิнка, ва̀ни, ваิн (Рамић 1999: 391), на Гламочу: вӓнка (Бојиновић 2015: 118), код личких јекавца: ва̂н, на̀ ва̄н, с ва̀на, ва̀ни (Драгичевић 1986: 176), на Банији и Кордуну: ва̂н, на-ва̂н, на-ва̀ни, изва̀на (Петровић 1978: 123), у Поткозарју: ва̂н (Далмација 2004: s. v.). По Црној Гори с источном Херцеговином сусрећемо префигиране прилошке форме, изван, на пример у црмничком говору: извӑ̣н (Милетић 1940: 227), у Зети: извӓн (Башановић-Чечовић 2010: s. v.), у рубном, мрковићком говору:

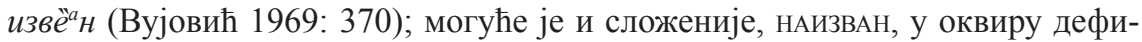
нисане просторне целине: у говору Куча: наизв' $a^{e} \boldsymbol{\mu}$ (Петровић и др. 2013: 236), у средњокатунским и љешанским говорима: наизвӓн (Пешикан 1965: 241) [с предлогом изван (1965: 191; уп. у плавско-гусињском говору Рековић 2013: s. v. izvæ̈n, prijed.)], у Пиви: найзван (село Безује, Гаговић 2004: s. v.) и на једном пункту у јужној Босни: найзван (муслиманско село Умољани у општини Трново, Ђуровић 1992: 321). У југозападном појасу (претежно садашња Црна Гора) придев извАњИ, па и творбено млађи извАњски, односно извАнски специјализују се у значењу 'који је нешто даљи у сродству, родбинским односима, индиректни - нерођени', гдегде и 'страни', уз задржавање општег значења 'спољашњи' - у Црмници: изва̣̂нскй, ређе изва̣̂fьскй (Милетић 1940: 367), у средњокатунским и љешанским говорима: извӓньй и изваิғский (Пешикан 1965: 241), Његушима: изваิњскӣ (Оташевић 2012: s. v.), Зети: извӓньй (Башановић-Чечовић 2010: s. v.), Никшићу: иेзвањ й (Ђоковић 2010, Ђоковић 2005: s. v.), Ускоцима: ѝзвањй (Станић I: s. v.), Прошћењу код Мојковца: ѝзванй (Вујичић 1995: s. v.; уп. Ристић 2010: s. v.), Васојевићима: извӑ̣нй (Стијовић 1990: s. v.), Рожајама: йзвањй (Хаџић 2003: s. v.), србијанском делу Полимља: изва̀љй (Николић 1991: 525); сасвим ретко сачуван је придев вАњи - у Пиви, поред ѝзвањ $\bar{u}, \grave{u} з в а ғ с к \overline{u ~(Г а г о в и ћ ~ 2004: ~ s . ~ v .) . ~ Н а ~ и с т о м ~ п р о с т о р у ~}$ постоји и именица изВАНАЦ, односно изВАњАЦ 'странац, дошљак' - извӑ̣на̣ (Милетић 1940: 227), извӓғаи и изва̄њӓu, изваิғка у Загарачу (Ћупић Д./Ћупић Ж. 1997: s. v.), ѝзвањаu (Станић I: s. v.), изва́ғац (Ђоковић 2010, Ђоковић 2005: s. v.). У Речнику Његошева језика постоји само предлог извАн у значењу 'ван' и 'осим' и сви контексти су народни. Од одговарајућих придева јавља се само извАнски, али у црквенословенском микроконтексту: внутренски и извански (Његош I: s. vv.). У говору Дубровника, пак, постоји и именица извАњштинА, чешће него извАнштинА 'нешто несвакидашње, необично (нпр. јело, ствар)': изва́ъьӣиина, изва́ншӣина (Бојанић/Тривунац 2002).

С друге стране, прилози НАПољЕ и НАПОљУ, такође СПОљА, Придеви спољАшњи, ${ }^{2}$ спољњи, одн. спољни, иначе лексеме из истог деривационог гнезда, представљају српску иновацију донекле раширену науштрб старијих лексичких решења у народним говорима (савремени књижевни језик у међувремену је допринео њену распростирању у свакодневној употреби, чак и у дијалекту,

\footnotetext{
${ }^{2}$ УП. с истим творбеним формантом gанашњи, саgашњи, некаgашњи, јучерашњи, вечерашњьи итд. (-s-|-bn-j-, нпр. *dbnbs-bńb; овде је и шири сложени суфикс-spol-bnь: spol--bšbńb).
} 
што је примећено у дијалекатским студијама). Њихову дистрибуцију засад није могуће прецизно одредити - раширени су и уопштени по централној Србији (с тим што се у лексичким инвентарима углавном даје само први члан лексичке скупине), на пример у Драгачеву (Ђукановић 1995: 223), Ваљевској Подгорини (према нашем увиду), Љештанском (Тешић 1977: 303), итд., по читавој Војводини (РСГВ: s. v.), па и код Буњеваца: на̄ӣоље, найиљљу, сйӧља (Пеић/Бачлија 1990: s. v.), код Радимаца у Румунији, при чему прилогу нӓйоље опонира необично снӓйоље (Томић 1987: 417); донекле ограничено ка истоку и југу - у Црној реци у близини Бољевца (Марковић М. 1986: s. v.), на Тимоку: на́йољ (Кожељац 2014: s. v.), у Заплању: на́ӣоље (Марковић Ј. 2000: 190), Пироту: на́ӣoље (Златковић 2014: s. v.), на северу Метохије: нӓйол'e (Букумирић 2003: 293, Букумурић 2012: s. v.), допире преко подножја Игмана у Босни (село Мијановићи, Ђуровић 1992: 321) до западне Босне (Далмација 2017: s. v.) и личких јекаваца (Драгичевић 1986: 176). Пре Вукова Српског рјечника из 1818. тешко је пратити ову иновацију (нпр. у Даничић I-III нема ниједне потврде; примери из РЈАЗУ су XVII-XIX век, s. vv.); налазимо један пример код Гаврила С. Венцловића у Мачу духовном из 1736, с видљивом транзицијом у истом контексту ( $g$ вор $\rightarrow$ йоље, обоје у аблативном

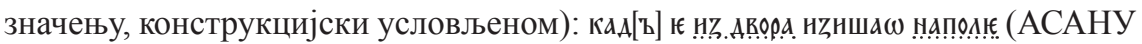
268, 101a, p. 20-21). ${ }^{3}$ Павле Ивић је добро уочио да у говору Галипољских Срба (стариначко српско становништво с конзервираним, предмиграционим језичким одликама из долине Велике Мораве, вероватно околина Јагодине), на̄йоје и на̄йоју имају само уже, основно значење, без доследног чувања разлике у њиховој употреби (1957: 308); у значењу 'споља' Галипољци имају прилог близак првом Венцловићеву прилошком споју: guзgвópa, сагласно прилозима за означавање правца кретања и места (Исто; уп. ниже).

У следећем унутрашњем прстену на који се настављају суседни инословенски говори, ${ }^{4}$ долазе архаични прилози, такође добијени срастањем, нАДвоР, НАДВОРУ (Понегде и зДвоРА) (спој НА-ДвоР је прасловенски, ЭССЯ: s. v. $n a d v o r z)^{5}$ - у Средачкој (Средској) жупи: на́gвор (Павловић 1939: 148, 253), Призрену: на́gвор (Реметић 1996: 385), на северу Метохије: наgворр (Букумирић 2003: 293, Букумирић 2012: s. v.) и уопште по Косову и Метохији: наgвоिр, нӑgвор и наgвоิ (Елезовић I: s. v.), у куршумлијском крају: наgвоิр (Радић 1990: s. v.), Прешеву: наgво́р (Трајковић 2016: 512), Врању: на́gвор, и у околини: на́gвар (Златановић 1998: s. v.), Црној Трави: наgво́р и нау́лище (Стојановић 2010: 490), Понишављу: наgвóp, наgво́рка (Ћирић 1999: 190), Тимоку: наgво́р (Динић 2008: s. v., Кожељац 2014: s. v.), Пироту: на́gвор, наgвóp, наgво́рка (Златковић 2014), код Галипољских Срба: нӓgвор, наgворру, уз gизяво́ра (Ивић 1957: 27, 110, 308), у Суботици: нӓgво̄p (РСГВ: s. v.); с дру-

\footnotetext{
${ }^{3}$ Докторанд Соња Манојловић овоме месту налази упориште у истоименој књизи Лазара

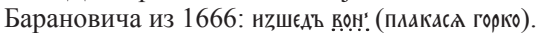

${ }^{4}$ Tо су македонски (РМJ: s. vv.) и бугарски - само у дијалектима (РБЕ: s. vv.); в. у нашој литератури за галички говор (Белић 1935: 235, 241-242) и горански говор (Младеновић 2001: 446).

${ }^{5}$ О континуитету сведочи један пример из Типика архиепископа Никодима (1318/1319):

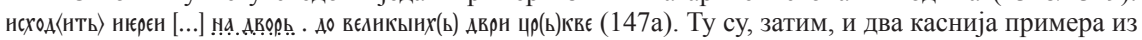
Даничићева Рјечника (I: s. v. Аворь - на дворог, foris; на двор, foras).
} 
ге стране, у мојковачком Прошћењу: на̀gвōp (Вујичић 1995: s. v.), Пиви: на̀gвōp (Гаговић 2004: s. v.), Никшићу: нӓgво̄p и зgворра (Ђоковић 2010, Ђоковић 2005: s. v.), Ускоцима: нӓgвōp, поред нӓgвора (Станић I: s. v.), Зети: нӓgво̄p (Башановић-Чечовић 2010: s. v.), Његушима: нӓgво̄p и прид. gворььи (Оташевић 2012: s. v.), на Конавлима: на̀ gво̄p (Кашић 1995: 374) и у самом Дубровнику: на̀gвōp, наgво́ру, зgво́ра, с посуђеним форра (Бојанић/Тривунац 2002: s. v.), односно gѐфорра (Младошић/Миливојевић 2011: s. v.), до Поткозарја: нàgвō (Далмација 2004: s. v.), околине Кључа у Босанској Крајини: на̀gво̄, нàgвop (Малбаша 1978: 104), Гламоча: нàgвō (Бојиновић 2015: 118), западнобосанских говора: на̀gво̄, наgво́рy, зgвóра (Дешић 1976: 273) и личких јекаваца: на̀gвōp, наgво́ру (Драгичевић 1986: 176). Занимљиво је да се лик наgво, с истом апокопом, очито као сведочанством унутрашње, генетске везе, јавља у међусобно удаљеним говорима, од Косова и Метохије до Поткозарја, Босанске Крајине, Гламоча и западне Босне (Бојиновић 2015, Далмација 2004, Дешић 1976, Елезовић I: нав. места).

У неким говорима укрштају се различита лексичка решења, на пример с потпуном синонимијом међу вАн (или сл.) и нАДвоР: у Лици (Драгичевић 1986: 176), Поткозарју (Далмација 2004: s. v.), на Гламочу (Бојиновић 2015: 118), у Конавалима (Кашић 1995: 374), Пиви (први парњак је найзван, Гаговић 2004: s. v.), Зети (први парњак је извӓн, Башановић-Чечовић 2010: s. v.), Призрену (Реметић 1996: 385). Тако, на северу Метохије постоје сва три решења (вӓн, нӓйол'e, наgвоिр), али је наgворр резервисано за југоисток (Букумирић 2003: 293 и нап. 520). У неким срединама у конкурентском односу су НАДвоР и НАПољЕ: на Тимоку (Кожељац 2014: s. v.), у Пироту (Златковић 2014: s. v.), с маргинализацијом првог у Војводини (само је један остатак на севеpy, у Суботици, РСГВ: s. v.). У Црној Трави јавља се јединствено решење: нау́лице, поред наgво́р (Стојановић 2010: 490, в. горе). Необично је то што се прилог спољА или на њега наслоњен придев јављају и у срединама у којима, судећи по литератури, [више] нема прилога нАПољЕ или је он резервисан за нешто друго: сйӧља (насупрот наизвӓн?, придеви су извӓнй и изваิњскй, Пешикан 1965: 241, 280), сиิољни (насупрот наgвоิр и сл., Елезовић II: s. v.), сйо́љан и сйо́љашан у Каменици код Ниша (Јовановић 2004: s. v.), сйо́љан у Црној Трави (поред наgво́р и нау́лище, Стојановић 2010: 490). Заправо, у некима од тих говора нАПољЕ се задржава или постоји само у изразима с карактеристичним значењем 'вршење нужде' (изићи, ићи, йоћи найоље и сл.) - у Црној Трави: на́ӣoље (Стојановић 2010: s. v.), Лесковцу: на́ӣoље (Митровић 1984: s. v.), Каменици код Ниша: на́йоље, а забележена је и изведеница на́йољица 'пролив' (Јовановић 2004: s. v.), у Ускоцима: на̄йоље (Станић I: s. v.). Наравно, у појединим говорима за прилог нАпоље потврђена су оба значења, па и ово: у Новом Милошеву у Банату: нӓйоље (РСГВ: s. v.), у говору Буњеваца (Пеић/Бачлија: s. v.) и у Качеру: маิло и вѐлико йӧље (Петровић/Капустина 2011: s. v.). И прилог нАдвор може у одговарајућим изразима имати исто значење - на северу Метохије: наgвоิр (Букумирић 2012, sub 2), у Пироту: нágвор/наgвóp, наgво́рка (Златковић 2014, sub 2), Ускоцима: нӓgворр (Станић I: s. v.); у тимочком крају посведочена је и именица наgво́рица 'пролив' (Ко- 
жељац 2014: s. v.). У другом Вукову Рјечнику забележена су оба случаја с помереним значењем (1852: s. vv. пољЕ (3), двоР (4. $\beta)$ ), наравно и у РСАНУ ( Такође и НАПОљИЦА, НАДВОРИЦА, s. vv.).

Вуков лексикографски рад одражава уједно и његово основно (дијалекатско) језичко искуство и ширење његова увида у стање у народним говорима (шири дијалекатски план), од 1818. до 1852. године. Иако ће други његов речник имати пресудан значај за обликовање српскога књижевног језика, неће се сав тај лексички садржај аутоматски пресликати у савремени књижевни језик. Нису сви потенцијали могли једнако бити искоришћени, посебно уколико су међу њима постојали какви конкурентски односи, што наши примери показују.

\begin{tabular}{|c|c|}
\hline Српски рјечник (1818) & Српски рјечник (1852) \\
\hline \multirow[t]{2}{*}{$\begin{array}{l}\text { Ва̀н, (у Ерц.) 1) als, außer, praetor [тј. } \\
\text { 'осим, до']: } \\
\text { „Ништо љепше и красније, } \\
\text { „Ван чарапа и опанак. } \\
\text { 2) ван да, außer wenn, nisi si, i. q. већ ако } \\
\text { [тј. 'осим, изузев ако']. }\end{array}$} & $\begin{array}{l}\text { вӓн, 1) praep. außer, extra: ван памети, } \\
\text { cf. изван. 2) hinaus, foras: отишао ван, т. } \\
\text { j. на поље. 3) draußen, foris, cf. ванка: он } \\
\text { је ван, т. ј. на пољу. 4) als, außer, praetor, } \\
\text { cf. осим, него до: } \\
\text { „Ништа љепше и красније } \\
\text { Ван чарапа и опанак - } \\
\text { Ван стајала те гледала - } \\
\text { 5) ван да, аußеr wenn, nisi, cf. већ ако } \\
\text { ['осим, изузев ако']. }\end{array}$ \\
\hline & ВӒнКА, draußen, foris. cf. ван. \\
\hline $\begin{array}{l}\text { Двоิр, m. 1) der Hof, der Hofpallast, aula, } \\
\text { palatium: у двору; код двора. 2) der } \\
\text { Haushof, aula: на двору: у двору као и на } \\
\text { двору (кисне); шта чиниш на двору те } \\
\text { не идеш у кућу? }\end{array}$ & $\begin{array}{l}\text { двоिр, дво́pa m. 1) der Hof, der Hofpallast, } \\
\text { aula, palatium: у двору; код двора. У } \\
\text { пјесмама се свака кућа зове gвор или } \\
\text { кула. 2) der Haushof, aula, cf. дво̀риште. } \\
\text { 3) на двору, draußen, foris: у двору као } \\
\text { и на gвору (кисне); шта чиниш на gвору } \\
\text { те не идеш у кућу? 4) на двор: } \alpha \text { ) hinaus, } \\
\text { foras; } \beta \text { ) um Nothdurft zu verrichten. 5) } \\
\text { с двора, von draußen, foris: дошао с } \\
\text { двора; улијепио кућу с двора, an der } \\
\text { Außenseite, extrinsecus. }\end{array}$ \\
\hline \multirow[t]{3}{*}{$\begin{array}{l}\text { Йзван, (по Ерц.) außer, extra: он је изван } \\
\text { себе. }\end{array}$} & $\begin{array}{l}\text { йзвАн, (по Херц.) (mit. gen.) außer, extra: } \\
\text { он је изван себе. }\end{array}$ \\
\hline & ЍзВАНКА, draußen, foris, cf. споља. \\
\hline & $\begin{array}{l}\text { йзвАњй, њâ, њê (у Паштр.), äußerlich cf. } \\
\text { спољашњи. }\end{array}$ \\
\hline Изну́тра, inwendig, intus. & изну́трА, inwendig, intus. \\
\hline $\begin{array}{l}\text { Ѝзнутрица, f. die innerliche Krankheit, } \\
\text { morbus internus. }\end{array}$ & $\begin{array}{l}\text { ЙзнутРИЦА, f. die innerliche Krankheit, } \\
\text { morbus internus. }\end{array}$ \\
\hline
\end{tabular}




\begin{tabular}{|c|c|}
\hline & $\begin{array}{l}\text { НУ̀тАРњИ̂, њâ, ње̂, (у Хрв.) innerlich, } \\
\text { internus. }\end{array}$ \\
\hline \multirow[t]{4}{*}{$\begin{array}{l}\text { По̀ље, n. 1) das Feld, campus. 2) на поље! } \\
\text { hinaus, foras; на пољу, draußen, foris; } \\
\text { с поља, von draußen, foris. 3) ћеpa ме } \\
\text { на поље, hinaus (um die Rothdurst zu } \\
\text { verrichten); so auch, mitten im Walde oder } \\
\text { Felde, отишао на поље. }\end{array}$} & $\begin{array}{l}\text { пӧље, n. 1) das Feld, campus. 2) на поље! } \\
\text { hinaus, foras; на пољу, draußen, foris; } \\
\text { с поља, von draußen, foris. 3) тjepa ме } \\
\text { на поље, hinaus (um die Nothdurft zu } \\
\text { verrichten); so auch, mitten im Walde } \\
\text { oder Felde: отишао на поље. }\end{array}$ \\
\hline & спӦљА, adv. von außen, extrinsecus. \\
\hline & $\begin{array}{l}\text { *[спољАшњИ, изостављено, али раније } \\
\text { најављено, sub извАњи }]\end{array}$ \\
\hline & унУ́тАР, vide унутра. \\
\hline \multirow[t]{2}{*}{ Уну́тра, drinnen, intus; hinein, intro. } & уну́тРА, 1) drinnen, intus. 2) hinein, intro. \\
\hline & у̀нУТРАШњИ̂, њâ, ње̂, innerlich, internus. \\
\hline
\end{tabular}

Вуку су 1818. познати предлози ВАН и изВАН и неколика предлошка споја, сви просторном употребом, према његову познавању прилика, сведени на Херцеговину. Насупрот томе он прилог изнутрА ничиме не маркира. У Рјечнику из 1852. повећава се број лексема из истога круга, а одредница вАн је и развијенија у првом делу. Пре свега, вАн више није територијално ограничено; то је сада и предлог, изједначен с херцеговачким извАн у значењу 'extra' (форма и значење данас обични у књижевном језику, в. РСАНУ, РМС, PCJ: s. vv.). На другом месту (2) Вук додаје прилошко значење 'foras', тј. 'напоље'; на трећем месту (3) прилошко значење 'foris', тј. 'напољу'. Такође, Вук своме вокабулару додаје придев, формално ослоњен на „херцеговачко” извАн - извАњи 'спољашњи', њему познат из Паштровића. Осим територијално раширених лексема унутрА и УнутрАшњИ, он доноси и придев нУТАРњИ ограничен на Хрватску, очито на српске (хрваћанске) говоре, у мери у којој су му били познати.

Иако су НАПољЕ и НАПОљу обрађени као Пододреднице Под ПољЕМ, с раздвојеним, етимолошким писањем, очито је да су то за Вука основна лексичка средства из ширег народног фонда. Исто тако је за Вука немаркирана прилошка форма спољА. Придев спољАшњи се подразумева, мада је случајно изостављен, јер га сусрећемо као упутницу с придева извАњи. Овога пута Вук разрађује и одредницу двор с одговарајућим значењима, опет без спојеног писања: (3) на двору 'foris', 'напољу' (у првом речнику 'aula', 'двориште, [непосредно] ван куће'); (4) на двор: $\alpha$ ) 'foras', тј. 'напоље'; (5) с двора 'foris', 'споља' и 'extrinsecus' 'изван' (премда је овде упућивање s. v. СПОљА).

Овде обухваћене лексичке јединице коришћене су у XX веку, између осталог, за поларизацију, а потом и разлучивање „западне” од „источне” варијанте „српскохрватског језика”. Доста је студија и приручника писано на 
ову ширу тему, више с хрватске него са српске стране. ${ }^{6}$ Већ у раним прегледима српско-хрватских лексичких разлика лингвисти су се могли сусретати с нашим примерима, у почетку само с некима од њих. У књизи Петра Губерине и Круна Крстића, објављеној уочи Другога светског рата у време формирања Бановине Хрватске (1939/1940), ,првом покушају” „да се у рјечничком погледу разграниче српска и хрватска језична пракса" (Губерина/Крстић 1940: $85),{ }^{7}$ читамо да је нАПољЕ одлика српскога књижевног језика, а вАн хрватскога (леви стубац у верзалу „припада српском језичном кругу”, Исто: 83):

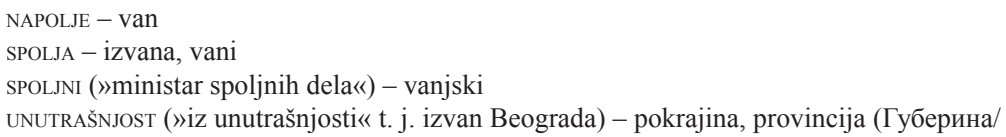

Више година касније, у три пута издаваном српско-хрватском варијантном речнику Јована Ћирилова $(1989,1994,2010)$, опет, читамо нешто другачије, али с оквирно истом диференцијацијом (но, у српској дефиницији аутор је користио придев вАњСКи):

izvana прил. споља. Са спољне, вањске стране.

izvanbračni прид. ванбрачни. [...]

izvanredne (mjere) прид. ванредне (мере). [...]

izvanredno stanje прид. и с. ванредно стање. [...

izvanji прид. спољашњи, који је споља, вањски.

izvanjski, в. izvanji.

nutarnji прид. унутрашњи, унутарњи. [...] Данас Хрвати употребљавају придев унуйрашњи.

vani прил. напољу, у иностранству. [...]

vanjska politika прид. и ж. спољна политика. Политика која се односи на иностранство.

vanjski poslovi прид. и м. мн. инострана дела.

vanjskopolitički прид. спољнополитички.

vanjština ж. спољашњост, спољашња страна нечега, спољашњи изглед, [...] (Ћирилов 2010: s. vv.).

Занимљиво је погледати како се представља вокабулар у једном опсежном хрватском речнику из новијег времена, на пример Владимира Анића (Анић 2003: s. vv.). Анић као дескриптивиста уноси у свој речник одреднице NAPOLJE и NAPOLJU, затим IZVAN и IZVANA (код прилога IZVANA У синонимском делу дефиниције на првом месту даје спољА, потом здворА). Аутор доноси придеве IZVANJSKI и VANJSKI (нема извАњи), не одређујући се према томе који

\footnotetext{
${ }^{6}$ Корисне информације пружа вишетомни зборник посвећен различитим погледима на односе између српскога и политичких језика настајалих на његовој основици, с прикупљеним старијим прилозима, под редакцијом Бранка Тошовића и Арна Вониша (Тошовић/Вониш 20102011). Међу новијим радовима у домаћој филологији в. Пипер 2008. (Пре)испитивање српско-хрватских језичких односа започето је у XIX веку, онда када је покренуто њихово програмско, не и природно зближавање, особито с једне стране, па су у томе учествовали неки од водећих лингвиста (у првој фази и Ђ. Даничић).

${ }^{7}$ Истини за вољу, у томе периоду јавља се и кратак прилог Р. Бошковића посвећен лексичким и стилским разликама (1935).
} 
је основни лик, мада други придев има два значења, 1. „који је извана...” и 2. „који се односи на иноземство”, за разлику од првога. Прилог VAN одређује као регионализам, упућујући за прво значење на обичније vANI (1. „изван мјеста или изван онога о чему је ријеч"), па чак и за остала значења на NAPOLJE (1. „(уз глаголе кретања) усмјерено према вани; ван” и 3. у функцији узвика „напоље!”). За прилог SPOLJA Анић напомиње да је регионализам, уз то и србизам, с упутницом на IZVANA. Пада у очи да он уопште не даје придеве спољАшњи и спољни, држећи их, ваљда, за србизме. Из овде реченог јасно се сагледава лексичко-творбена хетерогеност у хрватској варијанти овога језика, могућа само у случајевима вештачког грађења језичких навика у једној заједници, с разноликим језичким искуствима у исходишту.

У било каквом разматрању шире или уже проблематике, треба имати на уму да савремени стандардни језици представљају, делом, израз праксе и природних навика књижевнојезичке средине, а делом контролисан, посебно стимулисан израз, уобличен особеном селекцијом постојећих или чак новоостварених могућности. У језичкој нормативистичкој „лабораторији”, дакле, може се држати стања у народним говорима или властите књижевнојезичке традиције, па и дубље историје из различитих хронолошких пресека, но и не мора. Речено неупоредиво више важи за „наш” лингвистички запад него за исток. ${ }^{8}$ Стога, истицање разлика међу „стандардним” (или „књижевним”) језицима не игра нарочиту улогу јер се тиме не укида реалност, савремена, историјска или дијалекатска. У начелу, стандарднојезичка ситуација у различитим говорним срединама ослања се на другачије искуство од дијалекатскога - важно је зрачење медија и културно-образовних центара. То нас још једном подсећа на чињеницу добро знану дијахроничарима - „српски језик” и „стандардни српски језик” нису исто, стога и поређење с неупоредивим - нема вредност.

За разумевање актуелне књижевнојезичке ситуације на ширини српскога језичког подручја треба искључити Речник САНУ и Матичин шестотомни речник јер је њихов настанак везан за изучавање и репрезентовање српскохрватског језичког корпуса. У том смислу можемо се послужити Матичиним описним једнотомником из 2007, мада се чују приговори да се и у њему провлаче одреднице и конкретне обраде којима се продужава заједничко срп-

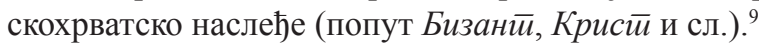

ва̂н и вӓн прил. (уп. вани) 1. (уз глаголе који означавају кретање) а. изван іраниия ояређеноі йростиора, найоље (изван куће, у йоље, на улииу, на ойворени йростиор): изаћи , погледати . б. изван среgине у којој се неко налази, ìge раgи и сл.: избацити (из партије,

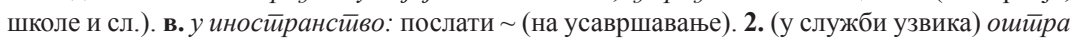
зайовесии некоме gа оgе: найоље!

${ }^{8}$ Појава, наравно, код нас веома позната, а насловима је добро илуструју два рада проф.

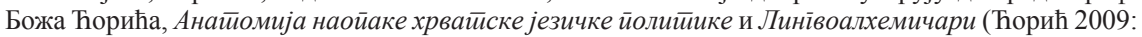
9-16, 17-25).

${ }^{9}$ Разуме се, ти су приговори упитни јер и даље има Срба католика којима су то обични облици (Дубровник, Бока Которска, па и Београд итд.); сетимо се и Решетарове прераде превода Старога и Новога завјета за католике међу Србима (Решетар 1895). На крају крајева, лингвисте су свесни - оваква питања не ограничавају се на припадност одређеним конфесијама. 
ван предл. (с ген.) изван (їраниц̧а, оквира нечеїа): изаћи града, родити дете брака. - себе (бити) нейрисебан, избезумљен. (сваке) сумње, (сваког) спора неосйорно, несумъиво, без сумье, свакако, сиіурно. памети неразумно, неразборийо.

ван- ирви део йридевских сложеница који означава gа је нешйо ван, изван оноїа шӣо значи йрияев: ванармијски, ванземаљски, ванпартијски, вансезонски итд.

ва̀ни и ва̀ни прил. (уп. ван) (обично уз глаголе који означавају мировање) 1. найољу,

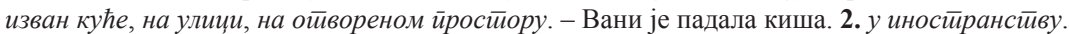
- Он ради негде вани.

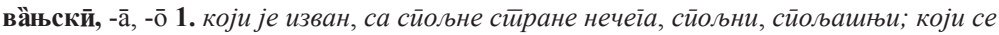

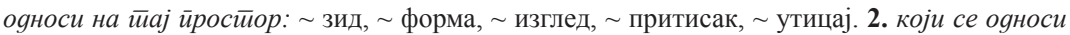

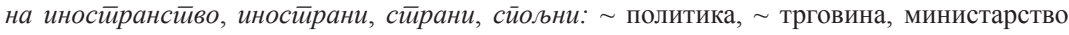
вањских послова.

изван (наглашено: ѝзван) предл. (с ген.) 1. не у ірраницама, не у оквиру, ван у йросйорном и временском смислу: града, куће; времена, до ручка. 2. ирекорачујући іранице, оквире, ойсеі 1) изнаg, ирреко: сваке мере 2) мимо, йройив: свих предвиђања. 3. изузев, сем, осим. - Вода све носи изван срамоте (НПосл).

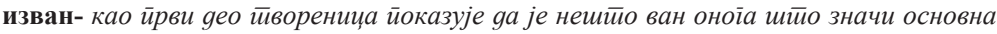
реч: изванвременски, изванземаљац, изванинституционалан, изванпансионски, извансезонски, извансеријски, изванстварносни, изванстраначки и др.

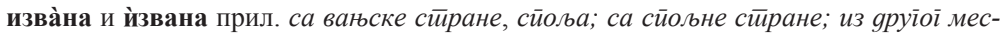
йa: окречити кућу .

ѝзвањй, $-\overline{\mathrm{a}},-\overline{\mathrm{e}}$ и ѝзвањскй, $-\overline{\mathrm{a}},-\overline{\mathrm{o}}$ сйољашњи; вањски: страна, ђак.

наัпоље прил. 1. а. (уз гл. кретања и опажања) (из)ван оgређеної кућної йростиора, ван куће, у gворишӣе, на улицу и сл.: изићи , погледати . б. на сйољну сиирану нечейа, (из)ван нечеїа: испасти ; врата се отварају . в. (из)ван среgине у којој се неко налази, у којој живи, раgи, борави: час у затвор, час . 2. (у служби узвика) йри ошйром зайовеgању

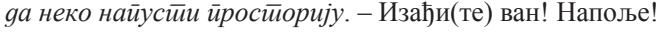

наупољу прил. (уз гл. мировања или ограниченог кретања) а. изван оgређене йросйоpије, куће, ван: бити (стајати, радити) . б. уойийе изван нечеїа зайвореної, оїраниченоі, йако gа не буgе обухваћено нечим, gа не буgе у склойу, сасӣаву нечеїа и сл. - Двоструки

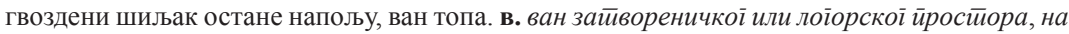
слободи. г. разг. изван земље (у којој живи лице које іовори), у иностирансйву.

спо̆ља прил. са сйољне, вағске сииране, извана: доћи, бити углађен.

спо̀љашњй, -ā, -е̄ 1. који је сйоља, сйољни, вағьки; супр. унутрашњи: зид, изглед. 2. в. сйољни (2).

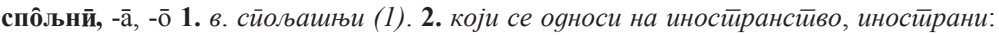
$\sim$ политика.

У Речнику српскога језика (2007), као и у ранијим речницима, не даје се предност једним или другим варијантама („источним” или „западним”), него се оне третирају као синоними. Лексеме се дефинишу готово истоветно, а потом се утврђује и еквиваленција међу њима: прилози вАН - НАПољЕ (обично Уз глаголе који означавају кретање), вАни - НАПољу (уз глаголе који означавају мировање или ограничено кретање), изВАНА - СПољА, ПридевИ ВАњСКИ (аЛИ и ИЗВАњИ, ИЗВАњСКИ) - СПОљАШњИ, ОДНОСНО СПОљНИ. ПосТОјИ И ИМеНИЦа вАњШтинА. Такође, регуларно је велики број придевских, али и именичких сложеница ослоњених на вАн-, мање него на извАн- (по нашем бројању, три пута више). Предлог вАн нарочито је присутан у неким изразима, али подробније је обрађено извАн (о свему РСJ: s. vv.). - Утисак је да је овакав приступ уравнотежен и да он у уважава разноврсност у животу српскога језика у свим његовим слојевима, без површног инсистирања на слици која је данас најраширенија у највећем, али не и једином српском центру. Сличан је приказ био и код Вука Караџића у другом Српском рјечнику, где се такође 
настојала приказати што шира српска језичка слика, али запажамо и ситније разлике. Код Вука је предлог извАн ограничен на Херцеговину, а данас је он на ширини српског простора можда и више употребљаван од предлога вАн. Још крупнија разлика - прилошки спојеви НАдвоР, НАДвОРу, здвоРА потпуно су изостављени у Речнику српскога језика, чиме им је одређен дијалекатски или покрајински статус (уп. РMC: s. vv. на̀дво̄p, здво́ра).

Књижевнојезичке потврде у великим домаћим речницима, пре свега Речнику САНУ и Матичину шестотомнику, показују нам да су „западне” лексеме заступљене код разних српских писаца, на пример Бранислава Нушића, Симе Пандуровића, Јована Дучића, Јована Јовановића Змаја, Бранка Радичевића. И обрнуто, оно што би се очекивало за источну варијанту, одомаћило се и код западних писаца, на пример Милана Беговића, Матије Мажуранића, Ивана Дончевића, Милана Марјановића, Антона Густава Матоша итд. (в. РСАНУ, РМС: s. vv.). Савремена употреба српског књижевног језика, нарочито као „стандардног” (премда је његова стандардизација у току), с могућношћу раздвајања говорне и писане праксе, захтева формирање посебно осмишљеног корпуса који би био осетљив за специфичне језичке ситуације, у којем би било места и за пасивни део фонда (на пример, за српске класике и школску лектиру), у којем би се уважавало постојање говорника и корисника српскога језика из различитих генерација и на различитом терену, и изван матичнога. Важно је начело да се судови о српском језику морају градити на основу укупне, а не парцијалне употребе српског језика (у Београду, Новом Саду, Крагујевцу, па и Нишу, али и Бањалуци, Требињу, Никшићу, па и Загребу, итд.). - Према нашем увиду, у савременој српској језичкој пракси на истоку (оној која припада књижевном језику или је под његовим утицајем) доминира ПриЛОшКИ НИЗ НАПОљЕ : НАПОљУ : СПОљА и У веЗИ с ПосЛедњИм посредно изведен придев спољАшњи. Приметна је дивергенција испољена у уобичајеним контекстима: спољАшњи 'који је са спољне стране, вањски', супротно од УнутрАшњи / спољни 'који се односи на иностранство, инострани', суПрОТно од НАЦИОНАЛНИ, ДОМАЋИ (на Пример, СПОљНИ обично иде уз назив министарства - Министарство спољних послова). Ипак, савремени српски, без обзира на фреквенцију и регионалну дистрибуцију, познаје и лексичке варијанте вАН, ВАНИ, вАњСКИ. Предлог иЗВАН, у одговарајућим контекстима и

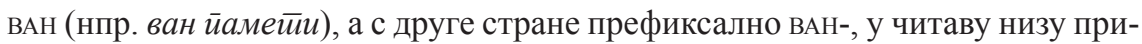
мера не могу се ничиме заменити.

Постоје и системски разлози када се у савременом српском језику мора УПотребити приЛог ВАН уместо НАПољЕ (саобразно овоме је и у другим лексичким паровима), што доказује да међу њима нема потпуног семантичког преклапања. Наиме, када одређени простор има најмање двостепену структуру, те вербално треба приказати излазак из ужег простора у шири (из ,затвореног” у „отворени”), и даље са задржавањем у унутрашњем оквиру (без апсолутног напуштања унутрашњости), неопходна је употреба неутралног лексичког средства - а то је прилог вАн (и остале форме из његова гнезда) јер на концептуалном плану он не садржи друга значења сем основног, 'foras', па се и дефинише једноставно: 'изван чега'. С друге стране, прилог нАпољЕ 
због прозрачне везе с мотивном речју (пољЕ 'ager, campus', тј. 'отворено, равно земљиште') потенцијално задржава оно значење из њена значењског спектра ('spatium', тј. 'отворен - релативно неограничен простор') које је и довело до иновативног лексичког исхода, праћеног трајним срастањем конституената и фиксирањем акценатског преноса (нАпољЕ 'ван'). Ово значење (нА-поље 'in spatium'), дакле, експонира се, тј. постаје видљиво у таквим контекстима, с могућношћу да поништи значењске нијансе које постављају логичко-семантички разлози. Зато се, на пример, за излазак из лифта у ходник, с кондензацијом исказа, не излази найоље (јер би то значило 'излазак из објекта'), него ван. Уједно, и да нема контекстуалних и семантичких ограничења, постојање праве предлошко-падежне конструкције нА + пољЕ, подударне по изговору с неповратно адвербијализованом формом, сметало би комуникацији (само у писању би због раздвајања било јасно). Уз речено, да се послужимо нашим терминима, постоје и случајеви „контекстуалне инерције” (поступање по аутоматизму) - када се у говору употреби предлог вАн, и када у наредној реченици изостане главни конститутент предлошко-падежне конструкције (недовршени исказ), да би се задржала структурна потпора, нормално је адвербијализовање предлога (на пример, бићу ван кyће ... бићу $\underline{\underline{b a \mu}) .}$. Д друге стране, иако се у дијалекатским студијама углавном недовољно обраћа пажња на предлог вАн, или извАн, наш је утисак да се барем један од ова два предлога обично користио на ширини српског простора, без обзира на судбину одговарајућег прилога, што би требало посебно испитати. - Све у свему, прилог вАн задржава основно, елементарно значење које се може односити на просторне, временске и све друге односе. Зато је улазио и још улази у читав низ сложеница (разлози су, наравно и у подесности форме за уклапање с другим творбеним основама, језичкој економији: само један слог уместо два код извАн-).

У усмеравању савременога српског стандарда у обзир треба узимати укупну теренску и књижевнојезичку слику, релевантну историју и потребе система, ништа мање и потребе књижевнојезичке културе. Увек ће постојати раскорак између препорука и њихова реалног остварења, те се зато не треба заклањати иза дескрипције; она је, по природи ствари, због великог броја индивидуалних језичких реализација, као и због просторне и временске разуђености - хетерогена; стога су и различити избори у начелу увек могући. И Вук се 1845. године одлучио за „опћену правилност”, уз узимање у обзир потврда у народним говорима (уп. Ковачевић 2011: 14-15).

\section{ИЗВОРИ И ЛИТЕРАТУРА}

Анић 2003: V. Anić, Veliki rječnik hrvatskoga jezika, Zagreb.

Башановић-Чечовић 2010: Ј. Башановић-Чечовић, Рјечник іовора Зейе, Подгорица: ЦАНУ.

Белић 1935: А. Белић, Галички дијалекат, Срйски gијалекйолошки зборник, VII. 
Богдановић 1979: Н. Богдановић, Говори Бучума и Белог Потока, Срйски gијалекииолошки зборник, XXV.

Бојанић/Тривунац 2002: М. Бојанић, Р. Тривунац, Рјечник gубровачкої іовора, Сриски дијалекӣолошки зборник, XLIX.

Бојиновић 2015: М. Бојиновић, Рјечник гламочког говора, Срйски gијалекйолошки зборник, LXII, 1-246.

Бошковић 1935: Р. Бошковић, О лексичкој и стилској диференцијацији српскога и хрватскога књижевног језика, Наш језик, III, 277-282.

Букумирић 2003: М. Букумирић, Говори северне Метохије, Срӣски gијалекичолошки зборник, L.

Букумирић 2012: М. Букумирић, Речник іовора северне Мейохије, Београд: Институт за српски језик САНУ.

Вујичић 1995: М. Вујичић, Речник іовора Прошћења (коg Мојковца), Подгорица: ЦАНУ.

Вујовић 1969: Л. Вујовић, Мрковићки дијалекат, Срӣски дијалекӣолошки зборник, XVIII, 73-399.

Вук 1818: В. Стефановић, Срйски рјечник, истиолкован њемачким и лаииинским ријечма, Беч.

Вук 1852: В. Стеф. Караџић, Срйски рјечник, истиумачен њемачкијем и лаииинскијем ријечима, Беч.

Вукадиновић 1996: В. Вукадиновић, Говор Црне Траве и Власине, Срйски gијалекииолошки зборник, XLII, 1-317.

Гаговић 2004: С. Гаговић, Из лексике Пиве (село Безује), Срйски gијалекйолошки зборник, LI, 1-312.

Губерина/Крстић 1940: Petar Guberina, Kruno Krstić, Razlike između hrvatskoga i srpskoga književnog jezika, Zagreb: Matica hrvatska.

Далмација 2004: С. Далмација, Речник іовора Пойкозарја, Бања Лука: Глас српски.

Далмација 2017: С. Далмација, Рјечник їовора Срба зайаgне Босне, Бања Лука: Матица српска - Друштво чланова у Републици Српској.

Даничић I-III: Ђ. Даничић, Рјечник из киижевних сииарина срӣских, I-III, приредио Ђ. Трифуновић, Београд, 1975 [1863-1864].

Дерксен 2008: R. Derksen, Etymological Dictionary of the Slavic Inherited Lexicon, Leiden - Boston: Brill.

Дешић 1976: М. Дешић, Западнобосански ијекавски говори, Срйски gијалекиолошки зборник, XXI.

Динић 2008: Ј. Динић, Тимочки gијалекайски речник, Београд: Институт за српски језик САНУ.

Драгичевић 1986: М. Драгичевић, Говор личких јекаваца, Срйски gијалекйолошки зборник, XXXIII, 7-241.

Ђоковић 2005: Љ. Ђоковић, Говорни gраїуљи никшићкої краја, Београд: Интерпрес.

Ђоковић, Љ. 2010: Љ. Ђоковић, Рјечник никиићкої краја, Подгорица: ЦАНУ.

Ђукановић 1995: П. Ђукановић, Говор Драгачева, Срйски дијалекӣолошки зборник, XLI, 1-240. 
Ђуровић 1992: Р. Ђуровић, Прелазни говори јужне Босне и високе Херцеговине, Срӣски gијалекӣолошки зборник, XXXVIII, 9-378.

Елезовић I-II: Г. Елезовић, Речник косовско-метохиског дијалекта, Срйски

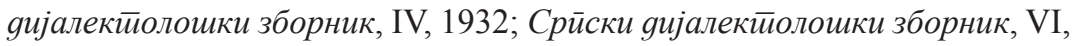
1935.

Жугић 2005: Р. Жугић, Речник говора Јабланичког краја, Срйски gијалекӣолошки зборник, LII.

Златановић 1998: М. Златановић, Речник іовора јужне Србије, Врање: Учитељски факултет.

Златковић 2014: Д. Златковић, Речник ӣиройской иовора, I-II, Београд: Службени гласник.

Ивић 1957: П. Ивић, О говору Галипољских Срба, Срӣски яијалекӣолошки зборник, XII.

Ивић и др. 1997: П. Ивић, Ж. Бошњаковић, Г. Драгин, Банатски говори шумадијско-војвођанског дијалекта, Срйски яијалекӣолошки зборник, XLIII.

Јовановић 2004: В. Јовановић, Речник села Каменице код Ниша, Срйски дијалекииолошки зборник, LI.

Јовановић 2007: В. Јовановић, Додатак Речнику села Каменице код Ниша, Сриски дијалекӣолошки зборник, LIV, 403-520.

Јокић 2012: B. Jokić, Rječnik veličkoga govora, Podgorica.

Кашић 1995: Z. Kašić, Govor Konavala, Срӣски дијалекӣолошки зборник, XLI, 241-396.

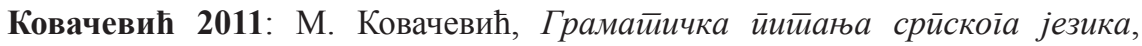
Београд: Јасен.

Кожељац 2014: Љ. Рајковић Кожељац, Речник ииимочкоі іовора, Неготин: Књижевно-издавачко друштво.

Копривица 2006: Ј. Копривица, Речник їовора Бањана, Грахова и Ойуйних Руgина, Подгорица: ЦАНУ.

Лазић 2008: А. Лазић, Грађа за речник іовора Мачве, Шабац: Културни центар.

Малбаша 1978: Z. Malbaša, Iz leksike sela Donjih Ramića kod Ključa u Bosanskoj Krajini, Прилози ирроучавању језика, 12, Нови Сад, 95-117.

Марковић J. 2000: Ј. Марковић, Говор Заплања, Срйски gијалекӣолошки зборник, XLVII, 7-307.

Марковић М. 1986: М. Марковић, Речник народног говора у Црној Реци, Срисски gијалекитолошки зборник, XXXII.

Марковић С. 2011: С. 3. Марковић, Говор Ужичке Црне горе, Срйски gијалекииолошки зборник, LVIII, 337-672.

Мијатовић 1983: Ј. Мијатовић, Прилог познавању лексике српских говора у Мађарској, Прилози ирроучавању језика, 19, Нови Сад, 149-177.

Милетић 1940: Б. Милетић, Црмнички говор, Срӣски gијалекитолошки збор$н и \kappa$, IX.

Митровић 1984: Б. Митровић, Речник лесковачкої іовора, Лесковац: Библиотека Народног музеја у Лесковцу. 
Младеновић 2001: Р. Младеновић, Говор шарпланинске жупе Гора, Срйски gијалекіиолошки зборник, XLVIII, 1-606.

Младошић/Миливојевић 2011: D. Mladošić, M. Milivojević, Naški. Dubrovački rječnik, Dubrovnik.

Недељков/Марковић 2015: Љ. Недељков, Б. Марковић, Дијалекатска лексикографија штокавског наречја (од 1818-2014. године) - библиографија, Сритски gијалекитолошки зборник, LXII, 247-326.

Његош I-II: Речник језика Пейра II Пейровића Њеїоша, Уредник М. Стевановић, Београд: САНУ и др., 1983.

Оташевић 2012: D. Otašević, Njeguški rječnik, Podgorica.

Павловић 1939: М. Павловић, Говор Сретечке жупе, Срйски gијалекииолошки зборник, VIII.

Пеић/Бачлија 1990: M. Peić, G. Bačlija, Rečnik bačkih Bunjevaca, Novi Sad: Matica srpska - Subotica: Subotičke novine.

Петровић и др. 2013: Д. Петровић, И. Ћелић, Ј. Капустина, Речник Куча, Срисски дијалекӣолошки зборник, LX, 1-461.

Петровић/Капустина 2011: Д. Петровић, J. Капустина, Из лексике Качера, Срйски яијалекииолошки зборник, LVIII, 1-336.

Пешикан 1965: М. Пешикан, Староцрногорски средњокатунски и љешански говори, Срйски gијалекииолошки зборник, XV.

Пипер 2008: П. Пипер, О природи граматичких разлика између српског и хрватског језика, Летиойис Майице срйске, књ. 481, св. 5, 840-850.

Радић 1991: П. Радић, Цртице о говору села Мрче у куршумлијском крају, Срйски gијалекӣолошки зборник, XXXVI, 1-74.

Рамић 1999: Н. Рамић, Ливањско-дувањски говорни тип, Срӣски gијалекйолошки зборник, XLVI, 263-426.

РБЕ: Речник на българския език, I-, София: БАН - Институт за български език, 1977-.

Рековић 2013: I. Reković, Rječnik plavsko-gusinjskoga govora, Podgorica.

Решетар 1895: Sveto pismo Staroga i Novoga zavjeta. Pregledano izdanje, priredio M. Rešetar. U Budimpešti.

PJA3У: Rječnik hrvatskoga ili srpskoga jezika, I-XXIII. Zagreb: Jugoslavenska akademija znanosti i umjetnosti, 1880-1976.

PМJ: Речник на макеgонскиой јазик (со срӣскохрвайски ииолкувања), I-III, Скопје: Институт за македонски јазик, 1961-1966.

PMC: Речник срӣскохрвайскоїа књижевноі језика, књ. I-III, Нови Сад - Загреб: Матица српска - Матица хрватска, 1967-1969; књ. IV-VI. Нови Сад: Матица српска, 1971-1976.

РСАНУ: Речник срйскохрвайскої књижевної и нарояної језика, I-. Београд: Српска академија наука и уметности - Институт за српски језик САНУ, 1959-.

РСГВ: Речник срйских іовора Војвоgине, 1-10, Редактор Д. Петровић, Нови Сад: Матица српска - Тиски цвет, 2000-2010.

PCJ: Речник срӣскоїа језика, редиговао и уредио М. Николић, Нови Сад: Матица српска, 2007. 
CJC: Slovnik jazyka staroslověnského, 1-52. Praha: Akademie věd České Republiky - Slovanský ústav, 1958-1997.

Скок I-IV: P. Skok, Etimologijski rječnik hrvatskoga ili srpskoga jezika, I-IV. Zagreb, 1971-1974.

CC: Старославянский словарь (по рукописям X-XI веков). Под редакцией Р. М. Цейтлин, Р. Вечерки и Э. Благовой, Москва, 1994.

Станић I-II: М. Станић, Ускочки речник, I-II, Београд: Научна књига, 1990-1991.

Станојевић 1911: М. Станојевић, Северно-тимочки дијалекат, Срӣски guјалекииолошки зборник, II, Београд, 360-463.

Ристић Д. 2010: Д. Ристић, Рјечник іовора околине Мојковца, Подгорица: ЦАНУ.

Стијовић 1990: Р. Стијовић, Из лексике Васојевића, Срйски gијалекйолошки зборник, XXXVI, Београ, 119-380.

Стијовић 2014: Р. Стијовић, Речник Васојевића, Београд: Чигоја штампа.

Стојановић 2010: Р. Стојановић, Црнотравски речник, Срйски gијалекӣолошки зборник, LVII.

Тешић 1977: М. Тешић, Говор Љештанског, Срйски gијалекӣолошки зборник, XXII, 159-328.

Томић 1987: М. Томић, Говор Радимаца, Срйски дијалекйолошки зборник, XXXIII, 303-474.

Тошовић/Вониш 2010-2011: В. Tošović, A. Voniš, Srpski pogledi na odnose između srpskog, hrvatskog i bošnjačkog jezika, I/1-3, Graz-Beograd.

Трајковић 2016: Т. Трајковић, Говор Прешева, Срйски дијалекйолошки зборник, LXIII, 277-578.

Ћирилов 2010: Ј. Ћирилов, Хрвайско-срӣски рјечник иначища и срӣско-хр-

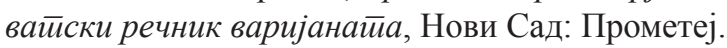

Ћирић 1999: Љ. Ћирић, Говори Понишавља, Срӣски яијалекӣолошки зборник, XLVI, 7-262.

Ћорић 2009: Б. Ћорић, Линївомаріиналије, Београд: Друштво за српски језик и књижевност Србије.

Ћупић Д./Ћупић Ж. 1997: Д. Ћупић, Ж. Ћупић, Речник іовора Заїарача, Срискки gијалекитолошки зборник, XLIV.

Фасмер I-IV: М. Фасмер, Этимологический словарь русского языка, Перевод с немецкого и дополнения О. Н. Трубачева, Издание второе, стереотипное, Москва: Прогрес, 1986-1987 [1950-1958].

Цветановић 2013: В. Цветановић, Речник зайлањской іовора, Гаџин Хан: Народна библиотека „Бранко Миљковић”.

Цвијетић 2014: Р. Цвијетић, Речник ужичкої іовора, Београд: Службени гласник.

Чешљар 1983: М. Чешљар, Из лексике Иванде (Румунски Банат), Прилози ироучавању језика, 19, Нови Сад, 107-148.

ЭССЯ: Этимологический словарь славянских языков. Праславянский лексический фонд, 1-. Под редакцией О. Н. Трубачева. Москва: Академия наук СССР / Российская академия наук - Институт русского языка им. В. В. Виноградова, 1974-. 
Viktor D. Savić

\section{VAN AND NAPOLJE, AND SIMILAR AND RELATED WORDS IN THE SERBIAN LANGUAGE: A CONTRIBUTION TO THE STUDY}

\section{Summary}

Based on limited historical and dialectal materials, the paper traces the development of the adverbial lexemes meaning 'out', 'outside', 'externally' in the Serbian linguistic context until the modern situation in the literatury language, which was unfoundedly manipulated in the $20^{\text {th }}$ century to polarize the two variants of the "Serbo-Croatian literary language". The paper presents ancient adverbialized nominal forms ( vernacular speeches (van, vani, izvan, naizvan), along with the distribution of the semantic shades of later adverbialized blends (napolje, napolju, spolja, nadvor, nadvoru, zdvora). The lexical and semantic diversity of terms in the dictionaries compiled by Vuk Karadžić is also discussed. These dictionaries served as the basis for the development and stabilization of the Serbian (and, in a wider perspective, Serbo-Croatian) lexicon. The paper also proposes principles for determining the normative status of these lexemes in the modern standard Serbian language.

Key words: van, vani, izvan, napolje, napolju, spolja, nadvor, nadvoru, zdvora, Serbian language, history with Serbian dialectology, contemporary language. 